\author{
ELWIRA BOLEK \\ (D) https://orcid.org/0000-0001-5874-6815 \\ Uniwersytet Marii Curie-Skłodowskiej w Lublinie \\ Lublin
}

\title{
Metafory w plakatach teatralnych Jerzego Czerniawskiego
}

\author{
Metaphors in Jerzy Czerniawski's theatre posters
}

\begin{abstract}
The paper analyses and interprets J. Czerniawski's artistic theatre posters. The aim of the research was to verify the assumption that multimodal metaphors are conceptual in their nature, to check how the detailed assumptions of G. Lakoff's and M. Johnson's conceptual metaphor theory match the analyses of artistic multimodal messages, and to confront this theory with C. Forceville's concept of multimodal metaphors. The specific goal was to attempt to define multimodal metaphors in an original way. The researcher puts forward a hypothesis, subsequently verified with analyses, that in the process of decoding the meanings of a poster, the images are read in conjunction with the words - titles of the performances, while the reception of the multi-code message constitutes mental negotiation (taking place in the recipient's mind) of the meanings of multi-level metaphors, in which language and image analogies result not only from their defined meanings, but also from the connotative features of verbal and non-verbal signs. The text fits within the framework of interdisciplinary cognitive research on artistic discourse.
\end{abstract}

Keywords: conceptual metaphor, multimodal metaphor, artistic theatre poster, Jerzy Czerniawski

Artykuł ma charakter aplikacyjny i konfrontacyjny. Analizy plakatów artystycznych Jerzego Czerniawskiego zostały w nim przeprowadzone w odniesieniu do teorii metafor pojęciowych George'a Lakoffa i Marka Johnsona, metafor multimodalnych Charlesa Forceville'a i metafory wielopoziomowej Ewy Szczęsnej. Z koncepcji tych wyzyskano to, co w analizach artystycznych przekazów multimodalnych wydaje się poznawczo korzystne. Jednocześnie uwzględniono szczególny charakter gatunkowy plakatu teatralnego, który z jednej strony pełni funkcję utylitarna, promocyjna - zachęca do przyjścia na konkretne widowisko, z drugiej strony należy do dyskursu artystycznego. 
Badania nad multimodalnością i metaforami multimodalnymi potwierdzaja konceptualny charakter metafory (zob. zbiór artykułów Multimodal metaphor 2009), ale też skłaniają do weryfikacji niektórych założeń koncepcji Lakoffa i Johnsona ${ }^{1}$. Skoro metafora ma charakter pojęciowy, to może zostać ucieleśniona w dowolnych znakach i za pośrednictwem różnych mediów. Lakoff i Johnson pokazuja, że w języku używamy konkretnych domen docelowych do rozumienia abstrakcyjnej domeny źródłowej. Natomiast w metaforach wizualnych i domena docelowa, i źródłowa są konkretne, choć cały wizualny lub multimodalny przekaz może traktować o wartościach abstrakcyjnych.

Rozpatrzyć należy też problem werbalnego opisu komunikatów niewerbalnych i multimodalnych. Podejście kognitywne pozwala na korzystanie z całego spektrum możliwości percepcyjnych i poznawczych człowieka, a więc zakłada również aktualizowanie wiedzy językowej przy odczytywaniu metafor niewerbalnych oraz dostrzeganie wpływu wizualności na metafory językowe. Należy jednak podkreślić, że słowny opis plakatów - nawet mimo wnikliwego podejścia analitycznego badacza - jest jedynie przybliżeniem wrażenia, jakie konkretny multimodalny przekaz może wywrzeć na odbiorcy.

Warto też wspomnieć o aspekcie widocznym na poziomie dalszych analiz - nakładaniu się na siebie metafor i ich treści w multimodalnym komunikacie kreatywnym. Znaczenie nie jest tu prostą sumą poszczególnych znaków, ale wypadkowa połączenia składników przekazu wchodzących ze sobą w wieloetapowe interakcje. Odbiorca dostrzega zarówno metafory monosemiotycze (językowe, wizualne) i transsemiotyczne ${ }^{2}$ (obrazowo-słowne). Niejednokrotnie w przekazie artystycznym zauważyć można kilka oddziałujących na siebie metafor, tworzących metafory wielopoziomowe. Według Ewy Szczęsnej

łańcuchowe nawarstwianie się relacji metaforycznych i w rezultacie kreowanie metafor wielopoziomowych daje efekt dyskursu metaforycznego, w którym znaczenia metaforyczne sa reinterpretowane na skutek wchodzenia w relacje metaforyczne z coraz to innymi składnikami przekazu (Szczęsna 2004, 169).

\footnotetext{
1 Zob. Johnson 2010, 2848-2850; Forceville 2009, 19-42; Libura 2012, 117-129.

2 Mimo przyjętego w badaniach nad metaforami obrazowo-słownymi terminu metafory multimodalne, przywołana zostaje w tym miejscu nomenklatura Ewy Szczęsnej, która zaznacza, że „przedrostek trans służy podkreśleniu faktu przenikania się znaczeń elementów wchodzących w relację metaforyczną, a nie ich sumowania” (Szczęsna 2007, 102).
} 
Deklarowane podejście multimodalne implikuje prowadzenie analiz z punktu widzenia odbiorcy - wnikliwego obserwatora-badacza, który stara się zrekonstruować globalny sens, uwzględniając możliwie wiele istotnych komponentów znaczeniowych wszystkich składników przekazu oraz dostrzegając szeroki kontekst (znakowy, tekstowy i kulturowy). Badacz ten nie podaje „prawidłowych” rozwiązań, a jedynie wskazuje pewien zbiór możliwości odczytywania metafor utrwalonych $\mathrm{w}$ plakacie ${ }^{3}$. Zaznacza, że procesy interpretacyjne są dynamiczne, a ich efekty zależne od dostrzeżenia (lub nie) i uwzględnienia (lub nie) kontekstów. Warto bowiem podkreślić, za Jolanta Maćkiewicz, że

odkrywanie czy raczej negocjowanie sensów, które zachodzi w procesie interpretacji polisemiotycznych i nieciagłych przekazów, odbywa się w ramach rozmaitych interakcji: między odbiorcą a przekazem, między przekazem a (szeroko rozumianym) kontekstem, między odbiorcą a kontekstem, między poszczególnymi składnikami przekazu (Maćkiewicz 2017, 41).

Obcowanie ze sztuką Czerniawskiego 4 powoduje, że „gubimy się w mrokach tajemnicy" (Szelegejd 1998, 89) - niby dostrzegamy w warstwie wizualnej znane znaki graficzne, a warstwa werbalna odsyła do tytułów rozpoznawalnych dramatów, ale wzajemne oddziaływanie słów i obrazów daje efekt zagadki interpretacyjnej.

W udzieleniu odpowiedzi na pytanie, dlaczego twórczość Czerniawskiego jest osnuta aurą tajemniczości, pomocne moga okazać się informacje o artyście oraz jego podejściu do pracy twórczej. Czerniawski jest erudyta, człowiekiem oczytanym, którego do stworzenia na plakacie teatralnym określonych przedstawień wizualnych inspirują nawet szczegóły zawarte w didaskaliach. Poprzez prezentację obrazów, czasem zupełnie niezwiązanych z głównym tematem dramatu, wyraża sprzeciw wobec oczekiwania, że artysta przedstawi na plakacie coś, co będzie jednocześnie zaskakujące oraz anonsujące i reklamujące daną realizację teatralną. Przy projektowaniu plakatów Czerniaw-

\footnotetext{
3 Por.: „Każdorazowa interpretacja metafory jest próbą intuicyjnego uchwycenia jej sensu próbą z natury rzeczy otwartą, nieobliczoną na znalezienie ostatecznego rozwiązania” (Dobrzyńska 2008, 26).

${ }^{4}$ Duży wybór plakatowej twórczości Jerzego Czerniawskiego, w tym niektóre $z$ analizowanych w artykule przekazów, znajduje się na stronie internetowej Galerii Plakatu Poster.pl: https: / www.poster.pl/plakaty/?page $=1$ \&designerId=0\&categoryId=0\&nationalityId=0\&fil $\mathrm{mNationalityId}=0$ \&actor $=\&$ authorId $=0$ \& theathreId $=0$ \&tagId $=0$ \&year $=0 \&$ onlyYear $=0 \&$ pri $\mathrm{ce}=0 \& \mathrm{hv}=0 \& \mathrm{q}=$ czerniawski_jerzy \&available $=0$ wyswietlaj $=1 \&$ added $=0 \& \operatorname{size}=0$.
} 
ski posługuje się własną techniką i przekracza granice gatunków sztuki. Tworzy niezwykłe podłoża, których gruba faktura imituje organiczne powierzchnie. Percepcja widza musi być więc skoncentrowana nie tylko na tym, co zostało przedstawione, ale też na sposobach wyrażania ekspresji twórczej. Odbiorca styka się z obrazami scalonych fragmentów różnych materii, zdeformowanych części ciała ludzkiego, zwierząt i przedmiotów. Wizualizowane obiekty są często zamglone lub jakby posypane warstwą drobnego piasku. Artysta posługuje się symbolem, metonimią i metaforą. Szczególnie interesująca wydaje się właśnie metafora, której główną zaleta, również w ujęciu samego artysty (Fijałkowska 1994, 94), jest otwartość na interpretację. W procesie odbioru plakatu obrazy są odczytywane w interakcji ze słowami. W efekcie wnikliwe interpretacje artystycznych plakatów teatralnych są negocjacją sensów wielopoziomowych metafor, w których analogie językowe i obrazowe nie wynikają tylko ze znaczeń definicyjnych, ale też z warunkowanych kulturowo cech konotacyjnych znaków werbalnych i pozawerbalnych 5 .

Dwa plakaty Czerniawskiego z jego bogatej kolekcji - Do Damas ₹ku i Gra snów - warto omówić łącznie, choć są zupełnie różne wizualnie. Oprócz tego, że oba odnoszą się do dramatów onirycznych Augusta Strindberga, to przyciagaja odbiorcę podobna tematyką: patrzenia, postrzegania, zmiany percepcji, ciekawości, iluzji, fałszu. Na plakacie do sztuki Gra snów uwagę interpretatora przykuwa duże, niebieskie oko przyglądające się czemuś przez dziurkę od klucza. Warstwa wizualna odczytywana jest przez odbiorcę za pośrednictwem obrazu mentalnego, wytworzonego pod wpływem znajomości faktów językowych. Wyrażenie zagladać, podgladać przez driurke od klucza można odczytać niedosłownie. Baza doświadczeniowa podpowiada, że przywołane połączenie wyrazowe może oznaczać nie tylko 'podglądanie', ale też 'ciekawość wywołaną przez utrudnione widzenie - brak całościowego oglądu sytuacji'. Samo podgladanie konotuje już przecież 'ciekawość'. Podglądacz - metonimicznie przedstawiony na plakacie za pomoca wizualnego znaku oka - nie wie, że po drugiej stronie drewnianych drzwi na haczyku zawieszony jest „klucz”, który nie ma typowego wyglądu ani nie pełni stereotypowej funkcji. W rzeczywistości to szpikulec, który po włożeniu do dziurki od klucza może przekłuć oko podglądacza. Odbiorca ma więc do czynienia z metaforą KLUCZ TO SZPIKULEC. Przedmiot, który służy do

\footnotetext{
5 Por.: „Interpretacje metaforyki są mocno uwarunkowane wiedzą potoczną, wartościami i ramami modalnymi charakterystycznymi dla danej kultury" (Lisowska-Magdziarz 2012, 125).
} 
otwierania, pozbawiony jest cechy definicyjnej, ale też konotacji 'pomoc', 'podpowiedź', 'rozwiązywanie'. W zamian zostaje nań nałożona cecha zadawania bólu, ranienia, kaleczenia. Klucz pełni przecież podwójną funkcję: nie tylko otwiera, ale też zamyka, uniemożliwia wyjście, więzi. Wydaje się, że klucz-szpikulec z plakatu może być właśnie tym negatywnym narzędziem, którym można zranić - „zamknąć” fizyczne widzenie. Oczywiście nie jest to jedyna możliwość odczytania. Otwarty charakter metafory pozwala wyznaczyć ścieżki interpretacyjne, na których należy dostrzec obie funkcje klucza (zamykanie i otwieranie) oraz nietypowe zakończenie narzędzia. Nie wiadomo też, po której stronie drzwi jest człowiek i na co patrzy: obserwuje świat z wnętrza (jest więc uwięziony), czy jest na zewnątrz pomieszczenia, które ogląda przez dziurkę od klucza. Rozważenie obu opcji znów pokazuje wieloznaczność plakatu. Jeśli podglądacz jest uwięziony, a klucz wisi na zewnątrz, to próba uwolnienia człowieka skończy się jednoczesnym pozbawieniem go możliwości widzenia, zamknięciem w prywatnym mroku. Jeśli obserwator zagląda do jakiegoś pomieszczenia, to nie zdaje sobie sprawy, że użycie klucza w celu otwarcia drzwi co prawda pozwoli zobaczyć, co jest w środku, ale też uniemożliwi mu oglądanie w ogóle, spowoduje utratę narządu wzroku. W obu przypadkach podgladanie oznacza więc 'widzenie pewnego wycinka rzeczywistości', ale też konotuje 'narażanie się na niebezpieczeństwo [oślepienia]'.

Takie odczytanie może być motywowane treścią anonsowanej sztuki. Tematem dramatu Strindberga jest sen rozumiany jako stan, w którym człowiek podgląda samego siebie, przygląda się nurtującym go problemom i pytaniom. Sen dla pisarza ,jest formą komentarza do życia, zwykle bardziej nawet bolesną niż samo życie" (Sokół 1977, LXXXIII). Można się pokusić o stwierdzenie, że w procesie interpretacji, w którym odbiorca uruchamia kontekst wymowy dzieła anonsowanego przez plakat, metafory nawarstwiaja się i w efekcie tworzą strukturę wielopoziomowa, zbudowaną z nakładających się na siebie domen: KLUCZ TO SZPIKULEC, SEN TO BOLESNY KOMENTARZ DO ŻYCIA. Klucz jest tu zatem pozbawiony konotacji 'pomoc' 'rozwiązanie', a sen - interpretowany jest jako czas bólu, ciagłego cierpienia, a nie jako stan odpoczynku. W kontekście sztuki Strindberga podglądanie samego siebie to działanie ryzykowne i niebezpieczne, grożące fizycznym bólem i ślepota, rozumianą również w sposób niedosłowny.

Warto jeszcze zasygnalizować, że tytuł Gra snów to również konstrukcja metaforyczna. W tym połączeniu wyrazowym aktualizuje się przenośne znaczenie gry jako 'stwarzania pozorów, udawania' (por. SJPDor). Wielopozio- 
mowa, multimodalna metafora (na którą składają się konstrukcje SEN TO GRA i KLUCZ TO SZPIKULEC), motywowana jest konotacjami 'ryzyka', 'niebezpieczeństwa', 'zagrożenia' łączącymi wszystkie znaczenia słów i obrazów. Można też odnieść wrażenie, że nadawca, budując multimodalny, niejednoznaczny, otwarty przekaz, gra z odbiorca-interpretatorem czy wręcz go zwodzi.

Plakat do drugiego onirycznego dramatu (a chronologicznie pierwszego) Do Damaszku również uruchamia myślenie metaforyczne odbiorcy i podobnie jak Gra snów jest silnie motywowany sztuką Strindberga. I w warstwie wizualnej, i na poziomie tekstu, do którego odsyła tytuł, zaobserwować można tę samą technikę przenikania się i nakładania obrazów (wizualnych i mentalnych). W drugiej części trylogii Strindberga, gdy Nieznajomy odkrywa, że padł ofiarą oszustwa, na scenie ,opuszcza się i przesuwa istny chaos dekoracji - krajobrazów, pałaców i pokoi, pod którymi znikaja postaci i meble" (Sokół 1977, LXXX). Na plakacie przedstawiona została droga ze szpalerem drzew. Wizualna reprezentacja drogi wchodzi w relację z tytułem sztuki, a multimodalną całość można odczytać jako „drogę do Damaszku”.

Nałożenie znaczeń związanych ze znakami werbalnymi i pozawerbalnymi oraz przywołanie kontekstu treści Strindbergowskiej sztuki wywołuje szereg skojarzeń, utrwalonych w metaforze pojęciowej ŻYCIE LUDZKIE TO DROGA (prayjsíc na swiat, isć przez. życie, wejsć w dany wiek / wejsć w dany etap w syciu, wiele przejśc w życiu, droga życia, kres ziemskiej węrówki - zob. Ożóg 2011, 15-25). Jeśli odbiorca uwzględni nawiązania intertekstualne, to zauważy, że utwór Strindberga odsyła do Biblii. W Driejach Apostolskich opisana została przemiana prześladującego chrześcijan Szawła w wiernego Pawła. Do Damaszłku to również dramat o nawróceniu: bohater - Nieznajomy w każdej części trylogii szuka swojej drogi przemiany. Między nim a Świętym Pawłem jest jednak zasadnicza różnica - Nieznajomego wciąż niepokoją wątpliwości.

Motyw drogi jako metafory ludzkiego życia jest obecny we wszystkich częściach dramatu. Ale czy droga wizualnie przedstawiona przez Czerniawskiego prowadzi do konkretnego celu? To raczej droga donikąd, droga bez celu lub błędna droga, która jest metaforą ludzi nieuporządkowanych, błądzących, niepoddających się racjonalności (Chudzik 2011, 35) - takich, jak Strindbergowski Nieznajomy.

Analizując metaforykę prac Czerniawskiego, warto też omówić dwa plakaty opracowane przez niego do polskich dramatów: Wyszedt z domu oraz $W y$ -

\footnotetext{
${ }^{6} \mathrm{Na}$ plakacie znajduje się niemieckie tłumaczenie tytułu: Er ging aus dem Hause... Komunikat jest tu jednak interpretowany z uwzględnieniem symboli i konotacji specyficznych dla polskich znaków werbalnych i pozawerbalnych. Autorka artykułu działania badawcze uzasad-
} 
spa róż: Tym razem elementem łączącym nie jest osoba autora dzieł literackich, których sceniczną adaptację anonsuja plakaty ${ }^{7}$, ale podobieństwo wizualne analizowanych artefaktów. W pierwszej kolejności omówiony zostanie plakat Wyszedt z domu, by w jego kontekście przeprowadzić interpretację niepublikowanego dzieła graficznego Wyspa róż: Na pierwszym plakacie widać część męskiej głowy, której twarz zastąpiona jest stopniami. Dostrzec można tutaj zastosowanie metonimii i metafory. Metonimia TWARZ ZA OSOBE to wyjątkowo produktywny przypadek uszczegółowienia CZEŚŚ ZA CAŁość. Lakoff i Johnson podkreślają, że

metonimia TWARZ ZA OSOBE nie jest jedynie sprawa języka. W naszej kulturze patrzymy na człowieka - bardziej niż na jego postawę czy ruchy - by uzyskać podstawowe informacje o nim. Funkcjonujemy w terminach metonimii, kiedy postrzegamy człowieka jako jego twarz i odpowiednio do tych postrzeżeń postępujemy (Lakoff, Johnson 2010, 69-70).

Warto podkreślić, że przedstawienie twarzy jako osoby powoduje otwarcie się odbiorcy nie tylko na fizyczność człowieka, ale odsyła do sfery psychicznej. Kulturowo twarz odnosi się do osobowości, intelektu bądź nastroju.

Punktem wyjścia do interpretacji metafory TWARZ TO SCHODY może być wydobycie asocjacji związanych z domeną źródłowa. Schody moga konotować zarówno ogólnie 'wyjście', 'wejście', 'przemieszczanie się, ale też kontekstowo 'problemy', 'trudności' (por. zaczynaja sie schody - 'zaczynają się kłopoty', 'sytuacja staje się trudna’). Wydaje się, że znajomość treści dramatu Różewicza może ukierunkować odbiór. W utworze literackim przedstawiona została historia Henryka - ojca, który pewnego dnia wyszedł z domu i nie wrócił do niego po pracy o stałej porze. Okazało się, że mężczyzna poślizgnął się na skórce banana, upadł i stracił pamięć.

Mieszczańskie nawyki, stereotypowe sądy, wszystko, co do tej pory definiowało funkcjonowanie rodziny, zostaje zapomniane, niejako unieważnione. Dotknięty amnezją mężczyzna jest szczęśliwy, bo nieświadomy ciężaru pustki swej dotychczasowej egzystencji ${ }^{8}$.

nia tym, że udostępniony jej projekt plakatu, będący w zakresie pomysłu graficznego identycznym z publikowaną wersja, został opatrzony polskim tytułem.

7 Wyszedt z domu to dramat Tadeusza Różewicza, a Wyspa róż właściwie nie jest dramatem, ale scenariuszem filmowym autorstwa Sławomira Mrożka.

8 http://ninateka.pl/audio/wyszedl-z-domu-tadeusz-rozewicz [dostęp: 08.02.2017]. 
W kontekście treści dramatu w procesie interpretacji metafory TWARZ TO SCHODY aktualizują się stereotypowe wyobrażenia o twarzy jako części ciała, która uzewnętrznia nie tylko emocje, ale też indywidualność charakteru. Sądy te zostały również utrwalone w języku, w następujących połączeniach wyrazowych: wyjśc z twarzq, ktoś bez twarzy. Finalnie można pokusić się o stwierdzenie, że Henryk przenośnie wyszedt z twarzq (rozumiana jako 'osobowość', 'godność'), którą razem z utrata pamięci stracił i teraz jest człowiekiem bez twaryy - 'kimś, komu brak indywidualności, osobowości, godności'. Taka interpretacja multimodalnej metafory jest uzasadniona przesłaniem dramatu, który mówi o trudnościach w odnalezieniu tożsamości.

Uderzającym podobieństwem w zakresie pomysłu kompozycyjnego odznacza się plakat powstały do dzieła Wyspa róż - przy czym umieszczony na nim kształt ludzkiej głowy nie jest „zbudowany” z materii żywej, biologicznej, a z czegoś, co przypomina cegły. Na plakacie do dramatu Wyszedt z domu został przedstawiony człowiek przeciętny, na drugim zaś - to raczej mur w kształcie ludzkiej głowy. Można tu dostrzec łańcuchowe nawarstwianie się domen następujących metafor: TWARZ TO MUR, TWARZ TO SCHODY, KAMIENNA TWARZ. Obraz Czerniawskiego jest niezwykle intrygujący, wywołuje u odbiorcy wręcz uczucie niepokoju. Trudno w treści scenariusza filmowego Wyspa róż (jest to utwór o Starcu, Mężczyźnie i Chłopcu - ostatnich członkach Zakonu Różokrzyżowców i Obcym - kobiecie, która niespodziewanie pojawia się na bezludnej wyspie) znaleźć uzasadnienie dla ponownego zastosowania metafory TWARZ TO SCHODY. Jedynym aktualizującym się kontekstem tłumaczącym jej użycie jest fakt, że zarówno obraz Czerniawskiego, jak i widowisko Mrożka są wielopłaszczyznowe, wieloznaczne i metaforyczne. Plakat ten należy więc zaliczyć do obszaru dyskursu artystycznego i dostrzec jego nieograniczoną otwartość na interpretację. Możliwe, że zabieg ponownego wykorzystania tej samej wizualnej metafory TWARZ TO SCHODY jest więc wynikiem filozofii plakacisty, który mówił przyjacielowi Jackowi Szelegejdowi, że jest już zmęczony szukaniem powiązań, relacji metatekstowych, więc projektem chce tylko zaskakiwać sam siebie. Motywacją takiego, a nie innego przedstawienia wizualnego jest więc sprowadzenie sztuki użytkowej do poziomu nieskrępowanej działalności twórczej. Może właśnie dlatego plakat nigdy nie był publikowany - prawdopodobnie jest jedynie artystyczną refleksją na temat sztuki czy filmu, które Czerniawski widział.

Artystyczne plakaty teatralne Jerzego Czerniawskiego to często monochromatyczne szarobure obrazy, przedstawiające zazwyczaj zdeformowane 
części ludzkiej twarzy lub osadzone w próżni elementy pochodzące ze świata przyrody. Nie zaciekawiaja odbiorcy obietnica przeniesienia do kolorowego świata sztuk plastycznych, ale kuszą zagadką i perspektywą przybliżenia się do jej rozwiązania dzięki procesowi interpretacji. Stosowanie przez artystę metonimii, metafory czy symbolu powoduje, że zaskoczony i zaintrygowany odbiorca nieustannie poszukuje przesłań tych wieloznacznych przekazów, próbując odnaleźć uzasadnienie i motywację określonych decyzji artystycznych w zakorzenionych w umyśle obrazach mentalnych i szeroko rozumianej wiedzy kulturowej. Podpowiedzi znajduje nie tylko w faktach językowych i znanych konwencjach graficznych, ale w całej dostępnej sferze doświadczenia, rozumienia, poznania - we wszelkich procesach mentalnych.

Poszukiwania interpretacyjne prowadzą do eksploracji metodologicznych i analitycznych. Przedstawione badania nad komunikacja multimodalna potwierdzaja konceptualny charakter metafory, ale też skłaniaja do weryfikacji metod Conceptual Metaphor Theory w ujęciu Lakoffa i Johnsona oraz stawiania kolejnych pytań o naturę metafor niejęzykowych. W artykule termin metafora multimodalna był używany intuicyjnie. W tym miejscu warto jednak sprecyzować jego rozumienie. Metafory multimodalne w odczuciu autorki szkicu to konstrukcje (zawarte w multimodalnych przekazach), których domena źródłowa i docelowa pochodzą z różnych systemów semiotycznych lub z jednego systemu semiotycznego, ale kontekst - konieczny do uwzględnienia, dookreślający sens - jest wyrażony w innym systemie niż sama metafora9.

\section{Bibliografia}

Chudzik A., 2011, Droga jako metafora jezykowa, w: Adamowski J., Smyk K., red., Droga w jezyku $i$ kulturze. Analizy antropologiczne, Lublin.

Dobrzyńska T., 2008, Dwudziestowieczne teorie jesykea wobec problemu metafory, „Studia Litteraria Polono-Slavica", t. 8.

El Refaie E., 2009, Metaphor in political cartoons: Exploring audience responses, w: Forceville Ch., Urios-Aparisi E., red., Multimodal metaphor, Berlin-New York.

\footnotetext{
9 Por. węższą definicję Ch. Forceville’a: „multimodal metaphors are metaphors whose target and source are each represented exclusively or predominantly in different modes" (Forceville 2009, 24) i definicję E. El Rafaire, która rozszerza kategorię metafor multimodalnych: „This, I propose, justifies their inclusion in the category of multimodal meta-phors, in which case Forceville's definition would need to be slightly extended to comprise all instances of metaphor where the target and source are represented exclusively, predominantly, or partially in different modes" (El Refaie 2009, 191).
} 
Fijałkowska J., 1994, Jersy Czerniawski, „Creation”, nr 20.

Forceville Ch., 2009, Non-verbal and multimodal metaphor in a cognitivist framework: Agendas for research, w: Forceville Ch., Urios-Aparisi E., red., Multimodal metaphor, Berlin-New York.

http://ninateka.pl/audio/wyszedl-z-domu-tadeusz-rozewicz [dostęp: 08.02.2017].

https: / www.poster.pl/plakaty/?page $=1 \&$ designerId $=0 \&$ categoryId $=0 \&$ nationalityId $=0 \&$ fil $\mathrm{mNationalityId}=0$ \&actor $=$ \&authorId $=0$ \& theathreId $=0$ \&tag $I \mathrm{~d}=0$ \&year $=0$ \&only Year $=0$ \& price $=0 \& \mathrm{hv}=0 \& \mathrm{q}=$ czerniawski_jerzy\&available $=0$ wyswietlaj $=1 \&$ added $=0 \&$ size $=0 \quad[$ dostęp: 18.10 .2020$]$.

Johnson M., 2010, Multimodal Metaphor, ,Journal of Pragmatics”, nr 42 (10).

Johnson M., Lakoff G., 2010, Metafory w naszym życiu, Warszawa.

Libura A., 2012, Teoria metafory pojeciowej wobec badań nad komunikacja multimodalna, w: Cichmińska M., Matusiak-Kempa I., red., Nowe zjawiska w jezylku, tekście i komunikacji. Metafory i amalgamaty pojeciowe, Olsztyn.

Lisowska-Magdziarz M., 2012, Obrazy ciała, obrazy produktu. Analiza metafor wizualnych $i$ multimodalnych w mediach masowych, w: Francuz P., red., Komunikacja wizualna, Warszawa.

Maćkiewicz J., 2017, Badanie medión multimodalnych - multimodalne badanie mediów, „Studia Medioznawcze" $\mathrm{Nr} 2$ (69).

Ożóg K., 2011, Metafora sycia ludžkiego jako drogi-aspekty jezylkowe i kulturowe, w: Adamowski J., Smyk K., red., Droga w jezykeu i kulturze. Analizy antropologiczne, Lublin.

SJPDor., http://sjpd.pwn.pl [dostęp: 08.02.2017].

Sokół L., 1977, Wstęp, w: Strindberg A., Wybór dramatów, Wrocław.

Szczęsna E., 2004, Metafora transsemiotycz̨na, „Pamiętnik Literacki”, nr XCV, z. 2.

Szczęsna E., 2007, Poetyka mediów: polisemiotycznosí, digitalizacja, reklama, Warszawa.

Szelegejd J., 1998, Miejsce śni sowicie, „Odra”, nr 6.

Elwira Bolek - mgr, Instytut Filologii Polskiej, Uniwersytet Marii Curie-Skłodowskiej w Lublinie, Lublin, Polska.

Jej zainteresowania naukowe dotyczą językoznawstwa kognitywnego, multimodalności, komunikacji wizualnej oraz metafory multimodalnej. Najważniejsze publikacje: Interpretacja plakatu artystycznego jako działanie na tekstach, w: Działania na tekście. Przekład - redagowanie - ilustrowanie (Lublin 2015); Gra znakami i znaczeniami w polskim artystycznym plakacie teatralnym, "LingVaria” 2018, nr 1; Język i obraz w plakacie teatralnym - analizy multimodalne, w: Współczesne media - media multimodalne, t. 1: Zagadnienia ogólne i teoretyczne. Multimodalność mediów drukowanych (Lublin 2018).

Kontakt: elwira.bolek@poczta.umcs.lublin.pl 